Available online at http://journal.stkip-andi-matappa.ac.id/index.php/histogram/index

Histogram : Jurnal Pendidikan Matematika 4(1), 2020, 45 - 64

\title{
PENGEMBANGAN TASK-DESIGN PADA MATA KULIAH ESENSI MATEMATIKA
}

\author{
Tanti Listiani ${ }^{*}$ \\ ${ }^{1}$ Universitas Pelita Harapan \\ * Corresponding Author. Email: tanti.listiani@gmail.com \\ Received: 1 Februari 2020; Revised: 27 Februari 2020; Accepted: 30 Maret 2020
}

\begin{abstract}
ABSTRAK
Esensi Matematika merupakan mata kuliah yang diberikan kepada seluruh mahasiswa FIP UPH. Mata kuliah ini biasanya diberikan kepada mahasiswa pada tahun pertama memasuki perkuliahan. Permasalahan yang dihadapi oleh mahasiswa yang sudah mengambil matakuliah ini adalah nilai UTS mahasiswa yang rendah. Tujuan dari penelitian ini adalah untuk mendeskripsikan pengembangan task design yang digunakan dalam mengatasi kesulitan belajar mahasiswa dalam belajar esensi matematika. Penelitian ini menggunakan design penelitian-Task Design dengan kerangka metodologi penelitian Didactic Engineering (DE). Pemilihan design penelitian ini adalah karena esensi matematika merupakan mata kuliah yang dapat mengajak mahasiswa untuk dapat melihat keindahan ciptaan Tuhan. Maka dari itu, diperlukan suatu design pembelajaran yang didalamnya mencakup soal, tugas serta materi yang di dalamnya dapat mengukur kemampuan pemahaman mahasiswa. Teknik pengambilan sampel dilakukan secara purposive, yaitu mahasiswa yang mendapatkan matakuliah esensi matematika. Dengan design pembelajaran yang ada, dosen sebagai pengajar dapat memiliki suatu rangkaian pembelajaran yang bermakna selain itu juga mampu membantu mahasiswa dalam mengatasi hasil pembelajaran menjadi lebih baik lagi. Hasil penelitian menunjukkan bahwa task design perlu dikembangkan dengan merujuk pada modul pembelajaran, tugas, soal-soal latihan yang perlu memperhatikan integrasi dalam kehidupan sehari-hari serta pelaksanaan UTS dapat dilakukan dengan menggunakan Moodle.
\end{abstract}

Kata Kunci: Task Design, Esensi Matematika, Pengembangan

\section{ABSTRACT}

Mathematics essence is a course given to all of Teachers College students at UPH. This course is usually given to students in the first year of entering the College. Students problem who have taken this course is the low score of the middle test. The purpose of this article is to describe task design development which used to solve the student learning difficulties in learning mathematics essence. This study used a research design-Task Design within the framework of the Didactic Engineering (DE) research methodology. The selection of this research design is because the mathematics essence is a subject that can invite students to be able to see the beauty of God's creation. Therefore, we need a learning design that includes questions, assignments, and materials which can measure students' understanding ability. The sampling technique is done purposively, namely students who get the essence of mathematics courses. With the existing learning design, lecturers as facilitators can have a meaningful learning sequence while also being able to assist students in overcoming learning outcomes for the better. The results show that task design needs to be developed by referring to learning modules, assignments, practice questions that need to integrate for daily life and to applicate in the middle test using Moodle.

Keywords: Task Design, Mathematics Essence, Development

How to Cite: Listiani, T. (2020). Pengembangan Task-Design pada Mata Kuliah Esensi Matematika. Histogram: Jurnal Pendidikan Matematika, 4(1), $45 \quad-\quad 64$, doi: http://dx.doi.org/10.31100/histogram.v4i1.517

Permalink/DOI: http://dx.doi.org/10.31100/histogram.v4i1.517

Copyright $\odot$ 2020, THE AUTHOR (S). This article distributed under the CC-BY-SA-license.

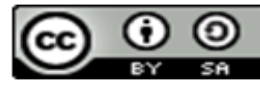




\section{Histogram: Jurnal Pendidikan Matematika, 4 (1), 2020 - 46 \\ Tanti Listiani}

\section{PENDAHULUAN}

Esensi Matematika merupakan mata kuliah yang diberikan kepada seluruh mahasiswa fakultas ilmu pendidikan di Universitas Pelita Harapan. Esensi Matematika merupakan mata kuliah yang unik diajarkan di FIP UPH, karena di dalamnya tidak hanya mengajarkan tentang isi atau content dari matematika itu sendiri namun mahasiswa juga bersama-sama diajarkan untuk melihat ternyata ada keindahan yang bisa dilihat dari matematika. Mata kuliah ini biasanya diberikan kepada mahasiswa pada tahun pertama memasuki perkuliahan di FIP UPH. Seperti yang kita ketahui bahwa matematika yang biasanya diberikan oleh siswa di bangku SMA adalah matematika yang berfokuskan pada content atau isi materi pelajaran saja maka pada matakuliah ini kita dapat melihat keagungan Tuhan mengenai karya-karyaNya dalam matematika. Sesuai pendapat yang disampaikan oleh Smith (2016), guru dapat menunjukkan bagaimana menggunakan subjek pelajaran yang dipelajari siswa untuk menyatakan kemuliaan Tuhan.

Pada mata kuliah esensi matematika ini, mahasiswa akan diajak mengenal matematika dengan sudut yang berbeda. Topik-topik yang diajarkan antara lain mengenai barisan Fibonacci, golden rasio, logika yang tak lengkap serta Alpha dan Omega. Pada barisan Fibonacci, mahasiswa akan diajak untuk melihat pola keindahan ciptaan Tuhan pada barisan angka-angka. Pada golden rasio, ini merupakan topik lanjutan dan keindahan ciptaan Tuhan dimana mahasiswa akan melihat angka-angka misteri yang mana manusia memiliki keterbatasan untuk mengetahui secara pastinya, contohnya adalah bilangan Irrasional. Kemudian berlanjut pada materi logika yang tak lengkap, pada topik ini mahasiswa akan melihat kebesaran Allah menggunakan logika-logika yang selama ini sudah diterima atau yang sudah pernah dipelajarinya. Pada topik ini akan berkaitan dengan konten matematika berupa topik logika matematika. Selanjutnya adalah topik Alpha dan Omega, pada topik ini mahasiswa akan mempelajari hal-hal yang dimaksud dengan konsep terhitung, tak terhitung dan tak hingga.

Topik-topik ini berkaitan dengan konten matematika yaitu pada materi himpunan. Inti dari topik ini adalah manusia dapat melihat kebesaran Allah dan sebenarnya Allah sendirilah yang menjadi Alpha dan Omega dari semesta ini. Seperti buku yang ditulis oleh Nickel (2001) yang berjudul Mathematics is God silent, ternyata sangat memungkinkan sekali sebagai pengajar untuk dapat mengaplikasikan Integrasi dalam materi matematika. Contoh materi lain yang dapat dipelajari adalah aljabar, geometri, trigonometri dan kalkulus dasar. Nickel dalam bukunya juga menyampaikan bahwa "In teaching mathematics, Scriputures are artificially 'tacked on' and the students are encourages to learn mathematics for God's glory... To God, every item of His creation, invisible and visible, reflects back to Him the beauty, wonder, and infinity of His attributes." Artinya 


\section{Histogram: Jurnal Pendidikan Matematika, 4 (1), 2020 - 47 Tanti Listiani}

dalam mengajar matematika, Alkitab secara artifisial 'dilekatkan' dan para siswa didorong untuk belajar matematika untuk kemuliaan Allah "... Bagi Allah, setiap benda ciptaan-Nya, baik tidak terlihat dan terlihat, mencerminkan kembali kepada-Nya tentang keindahan, keajaiban, dan ketidakterbatasan dari atribut-atributnyaNya.

Berdasarkan pengalaman pengajar serta wawancara terhadap beberapa mahasiswa di Fakultas Ilmu Pendidikan UPH yang sudah mendapatkan mata kuliah esensi matematika, ditemukan bahwa lebih dari 50\% mahasiswa belum terbiasa dengan pembelajaran matematika yang diberikan di Perguruan Tinggi. Namun pembelajaran diakui sangat menarik karena ternyata mereka dapat melihat bahwa segala sesuatu yang diciptakan Tuhan termasuk matematika berjalan dengan begitu harmonis. Contoh dari pembelajaran yang menarik adalah banyak hal-hal disekitar yang ternyata memiliki angka-angka seperti pada barisan Fibonacci, seperti fraktal, cangkang keong, jumlah kelopak bunga aster, rasio pada bunga matahari, dan lainnya. Jika dilihat lebih jauh lagi, maka dapat ditemukan bahwa benda-benda tersebut memiliki rasio emas (golden ratio). Rasio emas jarang sekali di bahas di bangku SMA, namun ternyata terdapat hal-hal menarik yang bisa didapatkan, karena rasio emas $\left(\varphi=\frac{1+\sqrt{5}}{2}=1,618 \ldots\right)$ merupakan angka pembulatan sama seperti pi $(\pi=3,14 .$.$) . Nah angka-angka ini adalah termasuk bilangan Irrasional yang biasanya$ jika dibulatkan adalah angka yang paling mendekati. Dengan melakukan pembuktian kecil didalamnya, mahasiswa dapat melihat keunikan matematika dan mahasiswa dapat semakin mengagumi Tuhan Sang Pencipta.

Pada penelitian ini akan melihat lebih jauh mengenai bagaimana tanggapan mahasiswa setelah mereka mempelajari mata kuliah esensi matematika. Selain itu, akan melihat kembali bagaimana modul yang selama ini digunakan dalam pembelajaran matematika, serta tugas-tugas yang selama ini diberikan kepada mahasiswa. Mahasiswa mengeluhkan bahwa materi-materi yang diajarkan memerlukan pemahaman tinggi, sehingga hal ini juga yang mengakibatkan bahwa hasil belajar mereka terutama pada nilai UTS nya menjadi rendah. Adapun keluhan yang dihadapi adalah pada saat membuktikan bagaimana menemukan rasio emas, kemudian dalam membedakan mana saja perbedaan antara bilangan terhitung, tidak terhitung dan tak hingga serta mempelajari Mobius Band. Hasil penelitian dari (Nurhikmayati, 2017) menunjukkan bahwa rendahnya nilai mahasiswa dalam mengerjakan matematika dapat dilihat dari banyaknya kesalahan yang dilakukan mahasiswa dalam menyelesaikan soal, diantaranya kesalahan dalam memahami konsep matematika, kesalahan dalam perhitungan matematika sederhana serta tidak dapat mengaplikasikan konsep pada konteks yang sesuai, kesalahan strategi menyelesaikan masalah, dan masih banyak kesalahan-kesalahan 
internal lainnya. Oleh karena itu, diperlukan perhatian khusus untuk dapat meningkatkan pemahaman mahasiswa dalam belajar esensi matematika.

Salah satu cara yang dapat digunakan adalah task design yang diberikan oleh dosen sebagai pengajar dalam membangun pemahaman kepada mahasiswa. Task design dan proses belajar mahasiswa adalah sesuatu yang sangat berhubungan dan saling mempengaruhi. Apa yang dipelajari oleh siswa secara keseluruhan ditentukan oleh taks yang mereka hadapi dan mereka terlibat atasnya (Grevholm, Millman, dan Clarke, 2008). Design pembelajaran yang disusun didalamnya mencakup soal-soal, tugas-tugas serta materi-materi di dalamnya yang dapat juga mengukur kemampuan pemahaman mahasiswa FIP dalam belajar esensi matematika. Penelitian ini menggunakan rancangan design pembelajaran yang sesuai agar pembelajaran dapat berjalan dengan efektif. Termasuknya adalah instrumen yang sesuai digunakan untuk mengetahui pemahaman mahasiswa terhadap mata kuliah esensi matematika. Dengan design pembelajaran yang ada, diharapkan dosen sebagai pengajar dapat memiliki suatu rangkaian pembelajaran yang bermakna selain itu juga mampu membantu mahasiswa dalam mengatasi kesulitan belajarnya.

Tujuan penelitian ini adalah untuk mendesain dan mengembangkan rencana pembelajaran yang dapat mengakomodasi mahasiswa pada mata kuliah esensi matematika yang berkaitan dengan modul yang digunakan, tugas-tugas yang cocok yang diberikan serta model soal yang cocok khususnya bentuk soal ujian tengah semesternya. Sehingga rumusan masalah dari penelitian ini adalah task design seperti apa yang sesuai untuk mahasiswa Fakultas Ilmu Pendidikan dalam mempelajari esensi matematika dalam membantu nilai hasil belajarnya yang rendah. Penelitian ini bermanfaat bagi dunia pendidikan secara umum dan Fakultas Ilmu Pendidikan Universitas Pelita Harapan secara khusus. Hasil yang diperoleh adalah design dari modul pembelajaran, tugas, soal dan UTS yang akan tertuang pada kontrak perkuliahan. Kontrak perkuliahan yang tersusun diharapkan dapat meningkatkan kualitas pembelajaran pada mata kuliah esensi matematika.

\section{METODE PENELITIAN}

Penelitian menggunakan pendekatan kualitatif dengan menggunakan kerangka metodologi penelitian Didactic Engineering (DE). Alasan menggunakan metode ini adalah, karena metode ini cocok digunakan untuk penelitian yang berkaitan dengan pendidikan matematika khususnya penelitian pengembangan seperti pendapat yang disampaikan oleh (Artigue \& Mariotti, 2014). (Artigue \& Mariotti, 2014) mengungkapkan bahwa:

"As a research methodology, DE emerged with this ambition, relying on the conceptual tools provided by the Theory of Didactical Situations (TDS), and conversely contributing to its 
consolidation and evolution (Brousseau, 1997). It quickly became a well-defined and privileged methodology in the French didactic community, accompanying the development of research from elementary school up to university level [...] (Artigue, 1990, 1992). From the nineties, DE migrated outside its original habitat, being extended to the design of teacher preparation, and professional development sessions, used by didacticians from other disciplines [...] and also by researchers in mathematics education in different countries".

Yang artinya "sebagai metodologi penelitian, DE muncul dengan keinginan besar, yaitu berkaitan dengan konseptual yang disediakan oleh Teori Situasi Didaktis (TDS), dan selain itu bermanfaat juga sebagai penggabung dan pengembangan (Brousseau, 1997). Secara singkat dapat dikatakan sebagai metodologi yang baik dan unik di komunitas Pendidikan di Perancis, serta sebagai penelitian pengembangan dari tingkat Sekolah Dasar hingga Universitas [...] (Artigue, 1990, 1992). Pada tahun sembilan puluhan, DE keluar dari areanya, dengan memperluas menjadi desain untuk persiapan guru, dan sesi pengembangan profesional, digunakan juga oleh pendidikan dari disiplin ilmu lain [...] dan juga oleh para peneliti dalam pendidikan matematika di berbagai negara".

Metodologi DE ini terdiri dari empat tahapan yaitu: (1) Preliminary analysis, (2) Design and a Priori Analysis, (3) Implementation, Observation and data collection, dan (4) A posteriori analysis. Pada tahap prelimninary analysis, dilakukan analisis konten yaitu analisis epistemologinya dan bagaimana hal tersebut dapat diajarkan. Analisis epistemologi ini, berimplikasi pada analisis epistemological obstacles dan didactical obstacles, yaitu hambatan belajar akibat epistemologi matematika dan hambatan belajar karena pilihan didaktis. Tahap Design and a Priori Analysis, task design disusun berdasarkan hasil dari preliminary analysis. Task design ini diimplementasikan dan akan dianalisis bagaimana respon mahasiswa atas task design. Pada tahap keempat, hasil dari implementasi ini, menjadi dasar pengembangan dan validasi task design.

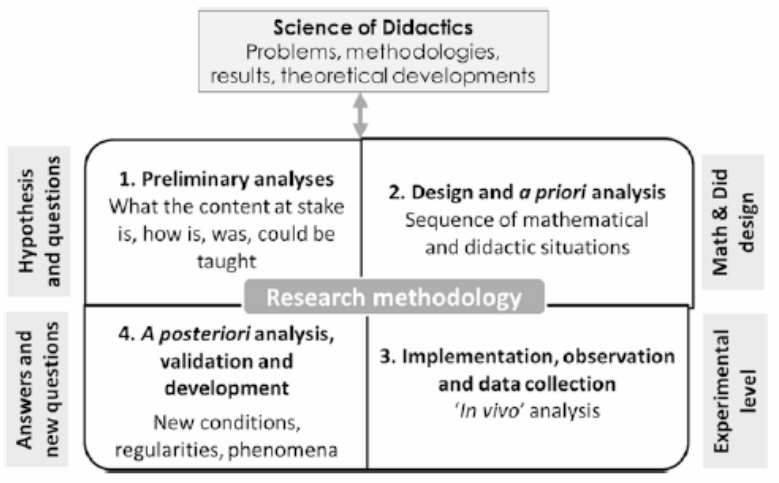

Gambar 1. Metodologi Penelitian DE 


\section{Histogram: Jurnal Pendidikan Matematika, 4 (1), 2020 - 50 \\ Tanti Listiani}

Penelitian ini hanya menggunakan tahap 1 dan tahap 2. Hal ini dipilih karena keterbatasan waktu dalam pelaksanaannya. Untuk itu, pada penelitian ini masih dibatasi pada tahap preliminary analysis dan design and a priori analysis. Hal ini dimungkinkan karena meskipun tahap-tahap DE ini merupakan satu kesatuan, tetapi juga dapat dilakukan terpisah untuk setiap tahapnya.

Tahap-tahap pada DE dapat membantu dalam mengkonstruksi task design. (Leung \& Bolite-Frant, 2015) menyampaikan beberapa hal yang dapat dipertimbangkan dalam mengkonstruksi task design, yaitu: (1) Epistemological and Mathematical Considerations; (2)Tool-Representational Considerations, (3) Pedagogical Considerations, (4) Discursive Considerations. Sementara Simon (1995), Clement dan Sarama (2004) serta Simon dan Tzur (2004) menyampaikan langkah-langkah dalam penyusunan task design, antara lain: (1) Analisis tujuan pembelajaran (learning goals); (2) Analisis perkembangan kemajuan pemikiran dan pembelajaran anak (developmental progression of thinking and learning), dan (3) Analisis perangkat aktivitas pembelajaran (sequence of instructional tasks). Pada penelitian ini akan digunakan pertimbangan yang disampaikan oleh (Simon, 1995),(Clements \& Sarama, 2004) serta (Simon \& Tzur, 2004).

\section{A. Tempat dan Waktu}

Penelitian ini dilaksanakan di Universitas Pelita Harapan (UPH) yang berlokasi di Jl. M.H. Thamrin Bouleverd, Kelapa Dua, Karawaci, Tangerang, Banten, Indonesia. Waktu pelaksanaan penelitian adalah semester genap tahan ajaran 2018/2019 dari bulan Januari-Juni 2019.

\section{B. Subjek Penelitian}

Partisipan dalam penelitian ini adalah mahasiswa pendidikan matematika Fakultas Ilmu Pendidikan Universitas Pelita Harapan, serta untuk mengetahui bagaimana pendapat mereka tentang modul pembelajaran yang digunakan maka subyek yang digunakan adalah mahasiswa angkatan 2018 sebanyak 38 mahasiswa yang menjadi responden. Mahasiswa sebagai responden adalah mahasiswa yang telah memperoleh mata kuliah esensi matematika pada semester itu.

\section{Metode Pengumpulan Data}

Penelitian ini hanya menggunakan 2 tahapan pada DE yaitu tahap 1 preliminary analysis dan tahap 2 design and a priori analysis. Pada tahap 1 yaitu preliminary analysis dilakukan analisis konten yaitu bagaimana materi esensi matematika diajarkan, serta hambatan belajar apa saja yang dijumpai saat belajar matematika. Maka pada tahap 1, metode pengumpulan data yang digunakan mengacu pada Task Design menurut Simon (1995), Clement dan Sarama (2004) serta Simon dan Tzur (2004) yang menyampaikan langkah-langkah dalam penyusunan task design, 


\section{Histogram: Jurnal Pendidikan Matematika, 4 (1), 2020 - 51 \\ Tanti Listiani}

antara lain: (1) analisis tujuan pembelajaran, (2) analisis perkembangan kemajuan pemikiran dan pembelajaran anak, dan (3) analisis perangkat aktivitas pembelajaran. Untuk memudahkan dalam memahaminya maka dapat dilihat pada Tabel 1 berikut:

Tabel 1. Kegiatan dalam Mengkonstruksi Taks Design

\begin{tabular}{|c|c|c|}
\hline Tahap & $\begin{array}{c}\text { Konstruksi Task } \\
\text { Design }\end{array}$ & Kegiatan \\
\hline \multirow[t]{3}{*}{$\begin{array}{l}\text { 1.Preliminary } \\
\text { analyses }\end{array}$} & $\begin{array}{ll}\text { Analisis tujuan } \\
\text { pembelajaran }\end{array}$ & $\begin{array}{l}\text { Menganalisis apakah tujuan pembelajaran } \\
\text { sudah terlaksana dengan baik termasuk } \\
\text { bagaimana pencapaian hasil belajar } \\
\text { mahasiswa }\end{array}$ \\
\hline & $\begin{array}{l}\text { Analisis perkembangan } \\
\text { kemajuan pemikiran } \\
\text { dan pembelajaran anak }\end{array}$ & $\begin{array}{l}\text { Menganalisis bagaimana tanggapan } \\
\text { mahasiswa dalam mengikuti perkuliahan } \\
\text { esensi matematika termasuk kesulitan dan } \\
\text { hambatan yang dihadapi }\end{array}$ \\
\hline & $\begin{array}{l}\text { Analisis perangkat } \\
\text { aktivitas pembelajaran }\end{array}$ & $\begin{array}{l}\text { Menganalisis modul yang digunakan, jenis } \\
\text { tugas yang diberikan termasuk metode yang } \\
\text { digunakan untuk ujian }\end{array}$ \\
\hline $\begin{array}{l}\text { 2.Design and a } \\
\text { priori analysis }\end{array}$ & $\begin{array}{l}\text { Design dilakukan berdas } \\
\text { mendesain ulang, meng } \\
\text { mengevaluasi task yan } \\
\text { mendorong munculnya a } \\
\text { ide dan strategi matematil }\end{array}$ & $\begin{array}{l}\text { arkan tahap } 1 \text { yaitu memilih, memodifikasi, } \\
\text { atur/mengurutkan, mengimplementasikan dan } \\
g \text { pernah digunakan. Task disusun untuk } \\
\text { ktivitas mahasiswa dalam menemukan konsep, } \\
\text { ka. Task yang di design berupa soal-soal, tugas- } \\
\text { yang diberikan kepada mahasiswa. }\end{array}$ \\
\hline
\end{tabular}

(Sumber:Data Primer, Tahun: 2019)

Kuisioner dilakukan untuk mengumpulkan data. Setiap partisipan mahasiswa kemudian diberikan kuisioner. Kuesioner terdiri dari 23 butir pernyataan dengan pilihan setuju, ragu-ragu dan tidak setuju. Hasil dari kuisioner ini menjadi dasar pada pemilihan partisipan mahasiswa yang terlibat dalam wawancara. Sementara dosen yang mengampu mata kuliah ini terlibat dalam penyusunan soal UTS. Pada tahap design and a priori analysis, didapat data mengenai task design yang sudah pernah digunakan baik di UPH maupun di tempat lain melalui diskusi. Kuisioner serta In-dept Interview dilakukan untuk mengumpulkan data. Setiap partisipan mahasiswa diberikan kuisioner, kemudian diwawancarai berkaitan dengan alasan kenapa mereka memilih pernyataan yang ada. 


\section{Histogram: Jurnal Pendidikan Matematika, 4 (1), 2020 - 52 \\ Tanti Listiani}

\section{Analisis Data}

Hasil kuisioner dianalisis secara deskriptif dengan menggunakan statistik deskriptif untuk melihat gambaran pemahaman mahasiswa mengenai epistemologi matematika sesuai dengan indikator yang digunakan. Data yang diperoleh dari hasil penelitian berupa data kualitatif yang dianalisis secara kuantitatif. Data kualitatif diperoleh dari kuesioner yang dibagikan kepada mahasiswa yang sudah mengambil mata kuliah esensi matematika, serta didukung dengan wawancara sebagai data pendukung. Setelah kuesioner diperoleh dilanjutkan pengolahan data yang dikonversikan menjadi data kuatitatif dan dilakukan pengolahan dengan menggunakan Microsoft Excel. Task design baru yang sudah dikembangkan perlu dilakukan uji coba untuk melihat keberhasilan dari penggunaan task design tersebut (pada tahap ini perlu dilakukan penelitian lanjutan).

\section{HASIL DAN PEMBAHASAN}

Task design dan proses belajar mahasiswa adalah suatu yang sangat berhubungan dan saling mempengaruhi. Apa yang dipelajari oleh siswa secara keseluruhan ditentukan oleh task yang mereka hadapi dan mereka terlibat atasnya (Grevholm, Millman, dan Clarke, 2008). Bahkan banyak ahli dan peneliti mengungkapkan bahwa task sebagai "the starting point of mathematical activity" (Watson \& Sullivan, 2008, hal.109) .

Watson dan Sullivan (2008) mendeskripsikan task sebagai pertanyaan-pertanyaan, situasisituasi, ataupun pengajaran yang digunakan ketika melaksanakan proses pembelajaran matematika. Task akan mendorong munculnya aktivitas yang memungkinkan siswa untuk berhadapan dengan konsep, ide dan strategi matematika. Peran pengajar atau dosen adalah memilih, memodifikasi, mendesain, mendesain ulang, mengatur/mengurutkan, mengimplementasikan dan mengevaluasi task tersebut. Oleh karena itu peran dosen dalam memilih task yang tepat akan menentukan proses pembelajaran matematika yang akan terjadi.

Dosen biasanya hanya memberikan task yang siap saji pada siswa. Siap saji berarti siswa tidak didorong untuk membentuk pengetahuannya sendiri, melainkan dikondisikan untuk menerima transfer sekumpulan konten. Bahkan jamak dilakukan adalah dosen mengemas materi menjadi sesuatu yang dapat disampaikan secara langsung tanpa perlu mahasiswa melakukan proses rekonstruksi. Pembelajaran ini dipilih karena dipandang sebagai sajian yang singkat padat dan efektif dari segi waktu. Proses belajar mengajar yang seperti itu akan membuat matematika hanya menjadi tumpukan fakta bersifat rote learning pada mahasiswa. 
Sebaliknya, dosen harus mengkonstruksi task atau menciptakan task design dengan mempertimbangkan beberapa hal seperti epistemology matematika, tingkat berpikir mahasiswa, hambatan belajar (learning obstacles) dan lintasan belajar mahasiswa. Tanpa proses berpikir yang didasari akan hal ini, dosen akan cenderung mengarahkan pembelajaran matematika pada berpikir imitatif (peniruan) dimana mahasiswa hanya meniru atau sekadar "menerima paket" dari dosen. Selain itu, dosen juga hanya akan menyusun task design yang hanya berorientasi pada penjabaran tujuan dan minimnya antisipasi pedagogis-didaktis. Implikasinya adalah task design yang dikonstruksi tidak mempertimbangkan keragaman respon mahasiswa atas situasi pembelajaran yang dikembangkan. Hal ini mengakibatkan rangkaian task design yang diajukan pada mahasiswa kemungkinan besar tidak dapat mengakomodasi keragaman lintasan belajar (learning trajectories) mahasiswa. Bahkan yang paling buruk adalah task design menjadi sekadar kumpulan kontenkonten yang diberikan pada mahasiswa. Learning Trajectory (LT) adalah serangkaian aktifitas belajar yang merupakan suatu alur belajar siswa untuk mencapai tujuan pembelajaran secara lebih bermakna (Evayanti, 2018) . Menurut Brousseau (2002, pengajar perlu mengetahui learning obstacles siswa, agar tujuan pembelajaran dapat terlaksana dengan lebih bermakna.

Hasil penelitian pengembangan ini diuraikan berdasarkan kerangka pada metodologi penelitian Didactic Engineering (DE). Ada dua tahapan yang dilaksanakan, yaitu tahap satu adalah tahap preliminary analysis, kemudian tahap dua adalah tahap design and a priori analysis.

\section{Tahap Preliminary Analysis}

Pada tahap ini dilakukan analisis awal yang terdiri dari 3 bagian yaitu (a) analisis tujuan pembelajaran, (b) analisis perkembangan kemajuan pemikiran dan pembelajaran anak, dan (c) analisis perangkat aktivitas pembelajaran. Berikut ini adalah penjelasannya:

(a) Analisis Tujuan

Analisis tujuan dilakukan untuk menganalisis apakah tujuan pembelajaran esensi matematika sudah terlaksana dengan baik termasuk bagaimana pencapaian hasil belajar mahasiswa. Mata kuliah Esensi Matematika merupakan matakuliah yang diberikan kepada seluruh mahasiswa Fakultas Ilmu Pendidikan untuk angkatan pertama perkuliahan. Mata kuliah ini diberikan untuk membawa mahasiswa melihat keindahan dunia sebagai ciptaan Allah melalui konsep matematika. Mata kuliah ini berisi konsep dasar matematika antara lain teori bilangan, deret bilangan, serta logika matematika yang sebelumnya juga pernah didapatkan mahasiswa ketika di sekolah menengah. Pada mata kuliah ini lebih menekankan pada pemahaman konsep, kemampuan berpikir logis mahasiswa serta kekreativitasan mahasiswa dalam membuat alat peraga matematika. Berikut ini adalah kompetensi yang diharapkan dicapai oleh mahasiswa dalam belajar esensi matematika: 
Histogram: Jurnal Pendidikan Matematika, 4 (1), 2020 - 54

Tanti Listiani

Tabel 2. Kompetensi Matakuliah Esensi Matematika

\begin{tabular}{clccc}
\hline No. & \multicolumn{1}{c}{$\begin{array}{c}\text { Kompetensi mata kuliah yang } \\
\text { terpenuhi melalui penilaian utama }\end{array}$} & & Penilaian & \\
\hline 1 & $\begin{array}{l}\text { Mahasiswa dapat mengidentifikasi pola } \\
\text { dalam matematika }\end{array}$ & $\sqrt{ }$ & $\sqrt{ }$ & \\
\hline 2 & $\begin{array}{l}\text { Mahasiswa dapat menghargai keindahan } \\
\text { ciptaan Tuhan melalui pola }\end{array}$ & $\sqrt{ }$ & $\sqrt{ }$ & $\sqrt{ }$ \\
\hline 3 & $\begin{array}{l}\text { Mahasiswa dapat mengerti konsep-konsep } \\
\text { matematika tentang sesuatu yang dapat } \\
\text { dihitung }\end{array}$ & $\sqrt{ }$ & $\sqrt{ }$ & \\
\hline 4 & $\begin{array}{l}\text { Mahasiswa dapat membedakan konsep } \\
\text { matematika tentang "terhitung", }\end{array}$ & $\sqrt{ }$ & $\sqrt{ }$ & \\
\hline 5 & $\begin{array}{l}\text { Mahasiswa dapat memahami hukum- } \\
\text { hukum tentang logika matematika }\end{array}$ & $\sqrt{ }$ & $\sqrt{ }$ & \\
\hline 6 & $\begin{array}{l}\text { Mahasiswa dapat membuat pembuktian } \\
\text { dengan menggunakan logika matematika }\end{array}$ & $\sqrt{ }$ & $\sqrt{ }$ & \\
\hline 7 & $\begin{array}{l}\text { Mahasiswa dapat mengerti bahwa konsep } \\
\text { tanpa nilai adalah tidak bermakna }\end{array}$ & $\sqrt{ }$ & & \\
\hline 8 & $\begin{array}{l}\text { Mahasiswa dapat mengembangkan } \\
\text { konsep yang nyata menjadi konsep yang } \\
\text { abstrak }\end{array}$ & $\sqrt{ }$ & & \\
\hline 9 & $\begin{array}{l}\text { Mahasiswa dapat mengevaluasi tentang } \\
\text { keadilan melalui konsep rata-rata }\end{array}$ & $\sqrt{ }$ & \\
\hline 10 & $\begin{array}{l}\text { Mahasiswa dapat membuat alat peraga } \\
\text { matematika untuk menarik orang-orang } \\
\text { untuk belajar matematika }\end{array}$ & & & \\
\hline
\end{tabular}

(Sumber: Data Primer, Tahun:2019)

Dari Tabel 2, mahasiswa mendapatkan task berupa soal UTS yang dikerjakan secara tertulis. Sementara UAS dilaksanakan dengan menampilkan pameran alat peraga matematika dengan topik-topik yang sudah di tentukan oleh dosen pengajarnya. Hasil penilaian dari beberapa semester yang terlewati, mahasiswa bermasalah pada nilai UTS, dimana lebih dari 50\% mahasiswa tidak memenuhi standar kelulusan. Namun mahasiswa terbantu dengan nilai UAS nya, sehingga mahasiswa dapat lulus pada matakuliah esensi matematika ini.

Untuk melihat bagaimana keberhasilan hasil UTS maka berikut ini ditunjukkan data-data mengenai hasil nilai UTS di beberapa kelas yang sudah mengambil mata kuliah esensi matematika. Untuk analisis content dapat dilihat pada rekapan data di Tabel 3. 
Histogram: Jurnal Pendidikan Matematika, 4 (1), 2020 - 55

Tanti Listiani

Tabel 3. Analisis Konten untuk Esensi Matematika di Semester Sebelumnya

\begin{tabular}{cccccc}
\hline No. & $\begin{array}{c}\text { Term/ } \\
\text { Sem }\end{array}$ & Prodi & $\begin{array}{c}\text { Total } \\
\text { mahasiswa yang } \\
\text { di ampu }\end{array}$ & $\begin{array}{c}\text { Jumlah } \\
\text { mahasiswa dengan } \\
\text { nilai >= 55 }\end{array}$ & $\begin{array}{c}\text { Persentase } \\
\text { lulus UTS }\end{array}$ \\
\hline 1 & $2016-1$ & MAT & 42 & 12 & 28,57 \\
\hline 2 & $2016-1$ & MAT & 42 & 25 & 59,52 \\
\hline 3 & $2016-2$ & PGSD & 39 & 0 & 0,00 \\
\hline 4 & $2016-2$ & PGSD & 42 & 9 & 21,43 \\
\hline 5 & $2016-2$ & PGSD & 39 & 19 & 48,72 \\
\hline 6 & $2017-2$ & PGSD & 45 & 21 & 46,67 \\
\hline 7 & $2017-2$ & PGSD & 45 & 21 & 46,67
\end{tabular}

(Sumber: Data Primer, Tahun: 2016-2017)

Dari Tabel 3, terlihat bahwa, persentase yang lulus UTS esensi matematika dapat dikatakan kecil yaitu dibawah 50\% mahasiswa mendapatkan nilai di bawah 55 dari 7 kelas yang pernah diajarkan untuk mahasiswa angkatan 2016 dan 2017. Artinya banyak mahasiswa yang mengaku kesulitan mengerjakan soal UTS esensi matematika.

Rendahnya hasil belajar mahasiswa memungkinkan bahwa mahasiswa masih merasa kesulitan berkaitan materi yang diajarkan, selain itu penggunaan modul yang selama ini diberikan dimungkinkan kurang membantu mahasiswa dalam belajar. Rendahnya hasil belajar menunjukkan bahwa tujuan pembelajaran belum terlaksana dengan baik karena nilai UTS mahasiswa yang masih rendah. Hal ini mengartikan bahwa materi esensi matematika belum dengan baik oleh mahasiswa. Artinya walaupun nilai UAS mahasiswa memenuhi standar, namun percuma jika mahasiswa tidak memahami isi dari esensi matematika tersebut dikarenakan UAS berupa project alat peraga. Untuk itu dilakukan analisis lanjut yaitu analisis perkembangan kemajuan pemikiran dan pembelajaran mahasiswa.

(b) Analisis perkembangan kemajuan pemikiran dan pembelajaran mahasiswa

Pada analisis ini, dilakukan analisis dari hasil kuesioner yang sudah diisi oleh mahasiswa. Hasil kuesioner yang diisi oleh mahasiswa menunjukkan bahwa jika mahasiswa mendapatkan skor 3 maka itu mengartikan bahwa mahasiswa setuju dengan pernyataan yang di buat. Sementara jika mahasiswa mendapat skor 2 artinya adalah ragu-ragu dengan pernyataan tersebut dan jika mahasiswa mendapat skor 1 maka mahasiswa tidak setuju dengan pernyataan yang ada. Setelah direkap ternyata mahasiswa lebih banyak setuju dengan pernyataan yang ada.

Hasil kuesioner untuk melihat pemahaman mahasiswa terhadap materi menunjukkan bahwa mahasiswa masih belum terbiasa dengan pembelajaran yang mengintegrasikan matematika 


\section{Histogram: Jurnal Pendidikan Matematika, 4 (1), 2020 - 56 Tanti Listiani}

dengan sudut pandang lain. Artinya materi-materi yang diberikan dianggap berbeda dengan materi yang diberikan saat SMA, dan hasil wawancara terhadap beberapa mahasiswa. Mereka merasa membutuhkan pemahaman tinggi dalam mempelajari esensi matematika.

Hasil kuesioner menunjukkan bahwa terdapat 35,79\% persen mahasiswa memilih jawaban yang bukan integrasi artinya mahasiswa masih belum dapat melihat keindahan ciptaan Tuhan dalam matematika. Kemudian terdapat 36,32 \% yang mengisi ragu-ragu akan pernyataan yang ada dan terdapat $27,89 \%$ yang memilih pernyataan yang merupakan integrasi. Terlihat bahwa ternyata persentase mahasiswa yang memilih pernyataan yang merupakan integrasi adalah paling sedikit. Artinya mahasiswa disini masih memiliki pandangan yang belum tepat dalam mengintegrasikan matematika dengan kebenaran Allah.

Saat diwawancara terdapat beberapa pendapat yang disampaikan oleh mahasiswa terkait pernyataan-pernyataan yang ada, salah satunya adalah karena mahasiswa masih menganggap bahwa sebenarnya tidak terlalu ada implikasi khusus yang dapat mereka rasakan dengan mempelajari matematika dengan sudut pandang yang berbeda. Padahal kalau sungguh-sungguh dipahami, semakin seseorang mengenal matematika maka seseorang tersebut akan semakin melihat betapa Agung dan besar-Nya Tuhan yang menciptakan hal-hal dengan begitu detail. Tuhan menciptakan bunga matahari, dimana terdapat rasio-rasio dan poligon-poligon yang begitu indah. Tuhan menciptakan cangkang kerang serta berbagai bentuk bangunan yang memiliki golden rasio, dan menciptakan pola bilangan termasuk barisan Fibonacci.

Matematika mengandung nilai-nilai yang berlaku dalam masyarakat yang dapat diimplementasi dalam kehidupan sehari-hari. Nilai-nilai yang terkandung dalam matematika antara lain nilai praktis dan nilai guna, nilai kedisiplinan, nilai budaya, nilai hiburan, nilai keindahan dan juga nilai demokrasi. Pembelajaran matematika hendaknya memperhatikan nilai-nilai yang terkandung dalam matematika, sehingga pembelajaran matematika dapat diintegrasikan dengan nilai-nilai yang berlaku di masyarakat dan matematika menjadi bermakna tidak hanya mempertajam penalaran dan mengembangkan intelektual saja tetapi juga membentuk budipekerti yang tinggi (Soeprianto, 2009) .

Banyak hal yang bisa dibahas dan mahasiswa juga dapat terlatih untuk berpikir kritis melalui perkuliahan esensi matematika ini. Menurut (Indira et al., 2018) berpikir kritis merupakan proses kognitif untuk memperoleh pengetahuan, jika seseorang berpikir kritis maka ia akan mudah dalam menyelesaikan masalah. Menyadari bahwa matematika adalah sebenarnya mengakui Tuhan itu sangat hebat, logika manusia itu terbatas tapi cukup untuk kehidupan manusia. Logika yang 


\section{Histogram: Jurnal Pendidikan Matematika, 4 (1), 2020 - 57 Tanti Listiani}

Tuhan berikan kepada manusia membantu manusia untuk berinteraksi dengan orang lain, namun logika Allah selalu tidak tertandangi. Karena Dia lah yang menciptakan segala isi di bumi ini.

(c) Analisis perangkat aktivitas pembelajaran

Pada bagian ini, dilakukan analisis mengenai penggunaan modul yang sudah digunakan, jenis tugas yang sudah diberikan, metode yang diberikan serta bentuk ujian yang digunakan pada esensi matematika. Analisis diperoleh dari hasil kuesioner yang telah diisi oleh mahasiswa. Dari permasalahan-permasalahan primer yang sering terjadi pada saat perkuliahan esensi matematika. Terdapat tiga indikator yang di analisis yaitu mahasiswa tingkat pertama belum terbiasa dengan pembelajaran matematika model baru, kemudian mengenai tanggapan mahasiswa setelah mengikuti perkuliahan esensi matematika dan yang terakhir adalah mengenai modul pembelajaran yang selama ini telah digunakan.

Berikut adalah Tabel 4 mengenai persentase permasalahan yang dihadapi oleh mahasiswa pada saat mengikuti aktivitas dalam perkuliahan esensi matematika.

Tabel 4. Analisis Permasalahan pada Esensi Matematika

\begin{tabular}{ccccc}
\hline Indikator & \multicolumn{3}{c}{ Persentase } & Total \\
\cline { 2 - 4 } & Setuju & Ragu-Ragu & Tidak Setuju & $\mathbf{\%}$ \\
\hline $\mathbf{1}$ & 44,74 & 26,32 & 28,95 & 100,00 \\
\hline $\mathbf{2}$ & 97,37 & 2,63 & 0,00 & 100,00 \\
\hline $\mathbf{3}$ & 66,32 & 24,74 & 8,95 & 100,00
\end{tabular}

(Sumber: Data Primer, Tahun: 2019)

Dari Tabel 4 terlihat bahwa sebanyak 44,74\% pada indikator 1 setuju yang berarti bahwa sebagian besar mahasiswa memerlukan pemahaman tinggi dalam belajar esensi matematika dan topik-topik pada esensi matematika membingungkan bagi mahasiswa dengan sudut pandang baru. Sementara pada indikator 2 terdapat 97,37\% mahasiswa memilih setuju terhadap pernyataan yang ada, dapat dikatakan walaupun mahasiswa merasa kesulitan dan membutuhkan pemahaman tinggi dalam mempelajarinya, mereka tetap merasa bahwa topik-topik yang terdapat pada esensi matematika menarik dan membantu mahasiswa mengenal kebesaran Allah. Sementara pada indikator 3 terdapat 66,32\% mahasiswa memilih setuju. Hal ini mengartikan bahwa mahasiswa merasa terbantu dengan modul yang diberikan selama ini. Namun terdapat jawaban yang kurang maksimal pada pernyataan mengenai penggunaan modul dengan bahasa Inggris.

Hal ini dimungkinkan terjadi, karena mahasiswa Fakultas Ilmu Pendidikan UPH adalah mahasiswa yang berasal dari berbagai daerah yang tersebar di seluruh Indonesia, dapat dikatakan tidak semua mahasiswa mahir dalam bahasa Inggris. Inilah yang membuat mahasiswa terkendala 
dalam mempelajari materi esensi matematika. Namun demikian, mahasiswa perlu dituntut untuk mempelajari bahasa Inggris untuk menghadapi tantangan dan mengikuti perkembangan jaman seperti saat ini. Menurut Pratiwi, Nurnaningsih, dan Setiyono (2017) bahasa Inggris penting diberikan kepada mahasiswa yang mengambil jurusan non sastra Inggris, hal ini dikarena bahasa Ingris merupakan bahasa asing pertama kali yang digunakan di Indonesia dan bermanfaat untuk menghadapi perkembangan dunia di bidang IPTEK. Termasuk sebagai calon pendidik/ guru matematika, mahasiswa perlu untuk belajar bahasa Ingris dan di perguruan tinggi kemampuan kosakata bahasa Inggris mereka akan semakin bertambah.

Selain dari penggunaan modul pembelajaran, maka analisis dilanjutkan mengenai metode yang digunakan saat UTS. Pada tabel di atas sudah ditunjukkan bahwa dari 2 tahun terakhir mahasiswa yang lulus UTS sangat kecil sekali dengan lebih dari 50\% mahasiswa gagal pada nilai UTS nya. Hal ini memungkinkan beberapa faktor yang mempengaruhi, beberapa faktor yang mempengaruhi adalah mahasiswa memang belum paham betul mengenai materi yang diajarkan. Hasil wawancara terhadap beberapa mahasiswa ditemukan pendapat dari mahasiswa yang mengatakan bahwa materi yang diajarkan berbeda dengan yang di UTS kan. Hal ini memunculkan beberapa pendapat yang diberikan oleh para pengampu mata kuliah. Yang pertama adalah, karena esensi matematika diajarkan di kelas parallel dengan beberapa dosen pengajar yang berbeda, namun soal UTS yang diberikan sama. Ditemukan bahwa penyebab terjadinya hasil belajar yang rendah adalah karena setiap dosen memberikan penekanan materi yang berbeda-beda terhadap mahasiswa yang diajarkan.

Meskipun dalam penyusunannya dilakukan secara bersamaan namun ternyata faktor kemampuan awal mahasiswa terhadap matematika juga berpengaruh. Seperti pendapat dari Widyastuti, Wijaya, Rumite, Marpaung (2018), yang mengatakan bahwa minat belajar matematika, efikasi diri juga dapat mempengaruhi kondisi siswa dalam belajar matematika. Program studi yang dipilih mahasiswa juga dapat mempengaruhi bagaimana tingkat kemampuan matematikanya, jika mahasiswa berasal dari prodi pendidikan matematika maka ia akan dengan mudah dalam mengikuti perkuliahan. Dan akan ada perlakuan yang berbeda jika mahasiswa berasal dari prodi seperti bahasa Indonesia, Prodi PGSD dan yang lainnya. Berdasarkan hasil analisis-analisis yang sudah dilakukan, maka akan dilakukan tahap selanjutnya yaitu tahap Design and A Priori Analysis.

\section{Tahap Design and A Priori Analysis}

Pada tahap design and a priori analysis ini akan dilakukan analisis mengenai data yang sudah terkumpul pada tahap pertama. Pada tahap pertama terlihat bahwa permasalahan primer mahasiswa terletak pada soal UTS yang rendah, maka penjelasan pada tahap 2 akan lebih banyak 
menyinggung tentang pelaksanaan UTS dan bagaimana soal yang diberikan. Pada tahap ini dilakukan design terhadap 3 bagian yang sudah dianalisis permasalahannya pada tahap pertama. Pada tahap pertama, sudah ditemukan permasalahan yang dihadapi oleh mahasiswa yaitu mahasiswa mendapatkan nilai yang rendah untuk UTS esensi matematika dari tahun ke tahun. Jika UTS masih rendah, maka ini mengartikan terdapat suatu faktor yang mempengaruhinya. Faktor yang mempengaruhi adalah materi yang belum tersampaikan dengan baik dan latar belakang mahasiswa yang berasal dari beragam prodi yang membuat mahasiswa merasa kesulitan dalam mengikuti perkuliahan esensi matematika.

Dari permasalahan tersebut maka, dosen sebagai pengajar perlu untuk memberikan modifikasi dalam pembelajaran yang berupa task design. Hal ini dilakukan agar tujuan pembelajaran dapat tercapai. Kurangnya pemahaman mahasiswa juga dapat dilihat dari ketidakmampuan mereka dalam menjawab pertanyaan-pertanyaan yang terkandung dalam esensi matematika. Pertanyaan-pertanyaan yang diberikan adalah pertanyaan yang berkaitan dengan nilai integrasi kehidupan mahasiswa terhadap matematika. Hasil analisis menunjukkan mahasiswa belum merasakan integrasi matematika dalam kehidupan mereka secara benar.

Dari permasalahan inilah maka diperlukan task design yang dapat membantu mahasiswa untuk memahami esensi matematika dengan baik. Berikut ini akan diberikan tabel perbandingan antara desain aktivitas pembelajaran yang lama dengan yang baru.

Tabel 5. Perbandingan Desain lama dengan Modifikasi

\begin{tabular}{|c|c|c|}
\hline $\begin{array}{c}\text { Perangkat } \\
\text { Task Design }\end{array}$ & Lama & Modifikasi Pengembangan \\
\hline Tugas & $\begin{array}{l}\text { Desain tugas yang } \\
\text { diberikan lebih banyak } \\
\text { tentang } \\
\text { matematika }\end{array}$ & $\begin{array}{l}\text { Desain tugas ditambahkan dengan soal-soal yang } \\
\text { berkaitan dengan integrasi tanpa mengurangi } \\
\text { content matematika }\end{array}$ \\
\hline $\begin{array}{l}\text { Materi } \\
\text { Pembelajaran } \\
\text { (modul } \\
\text { pembelajaran) }\end{array}$ & $\begin{array}{l}\text { Dibuat dengan PPT } \\
\text { dengan berbahasa } \\
\text { Inggris yang berisikan } \\
\text { materi-materi dengan } \\
\text { sedikit integrase }\end{array}$ & $\begin{array}{l}\text { PPT dengan bahasa Inggris serta ditambahkan } \\
\text { penjelasan-penjelasan mengenai integrase. Selain } \\
\text { itu modul perlu diterjemahkan terutama untuk } \\
\text { istilah-istilah yang jarang dijumpai oleh } \\
\text { mahasiswa tingkat pertama. }\end{array}$ \\
\hline $\begin{array}{l}\text { Pemberian } \\
\text { UTS }\end{array}$ & $\begin{array}{lr}\text { Desain } & \text { soal } \\
\text { digunakan } & \text { adalah } \\
\text { tertulis, terdiri dari soal }\end{array}$ & $\begin{array}{l}\text { Soal UTS didesain dengan memberikan soal-soal } \\
\text { integrasi dan UTS dilakukan dengan }\end{array}$ \\
\hline
\end{tabular}


Histogram: Jurnal Pendidikan Matematika, 4 (1), 2020 - 60

Tanti Listiani

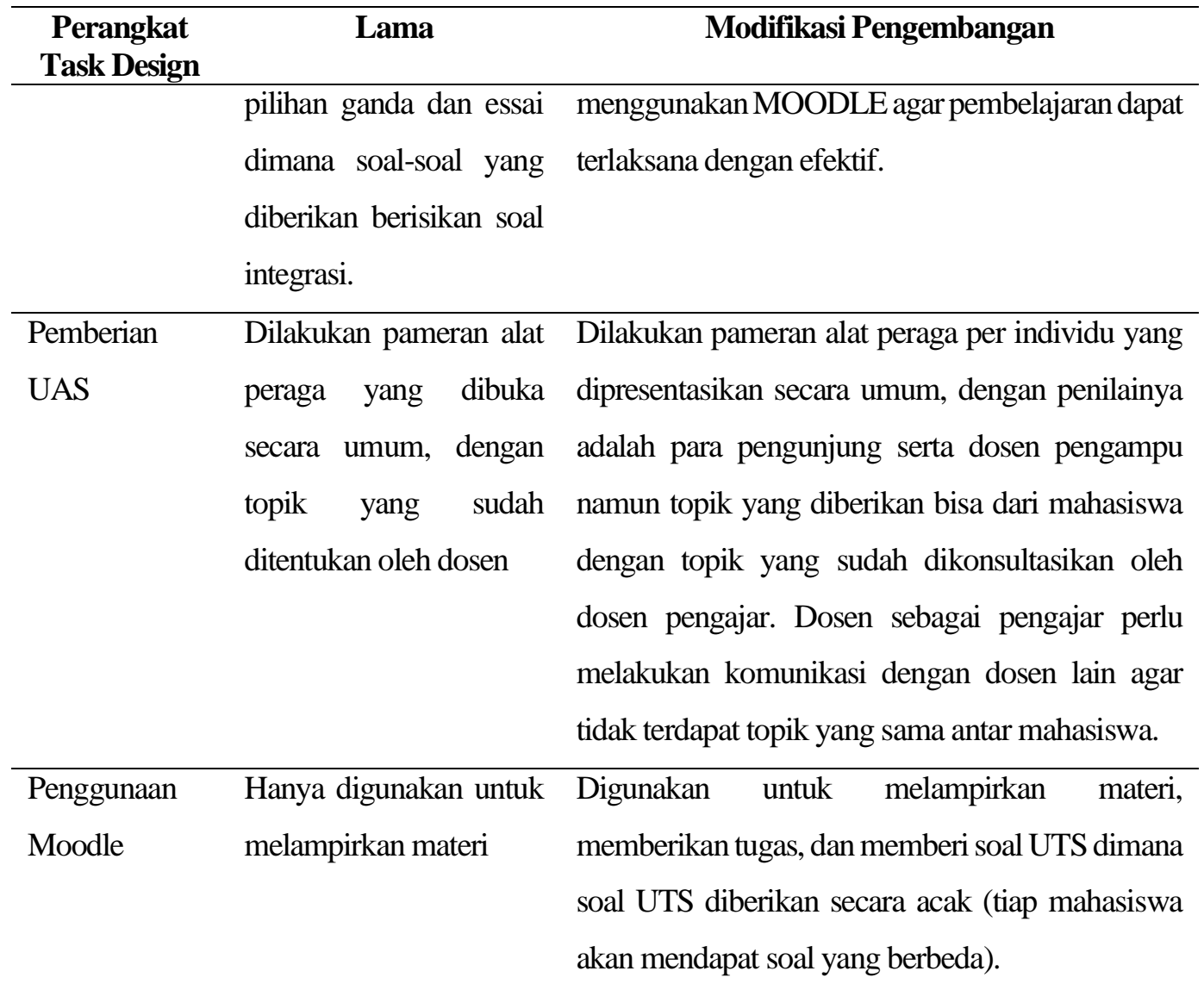

(Sumber: Data Primer, Tahun: 2019)

Sebagai usaha agar tujuan pembelajaran dapat terlaksana maka,pada Tabel 5 terlihat bahwa desain tugas yang diberikan merujuk pada penggunaan Moodle (Modular Object-Oriented Dynamic Learning Environment). Untuk memperkuat desain yang akan dilakukan nantinya maka dilakukan analisis penggunaan Moodle sebagai metode UTS mahasiswa. Berikut ini ditunjukkan analisis terhadap soal UTS yang sudah diberikan dan juga tanggapan mahasiswa mengenai UTS yang dilakukan menggunakan Moodle. Mahasiswa yang mengisi kuesioner adalah mahasiswa yang sudah pernah mengikuti UTS menggunakan Moodle. Berikut ini adalah rekapan hasil analisisnya:

Tabel 6. Analisis pada UTS

\begin{tabular}{ccccc}
\hline \multirow{2}{*}{ Indikator } & \multicolumn{3}{c}{ Persentase } & Total \\
\cline { 2 - 4 } & Setuju & Ragu-Ragu & Tidak Setuju & \% \\
\hline 1. & 69,74 & 21,71 & 8,55 & 100,00 \\
\hline 2 & 58,95 & 20,53 & 20,53 & 100,00 \\
\hline Rata-rata \% & 64,34 & 21,12 & 14,54 & 100,00 \\
\hline
\end{tabular}

(Sumber: Data Primer:, Tahun: 2019) 


\section{Histogram: Jurnal Pendidikan Matematika, 4 (1), 2020 - 61 Tanti Listiani}

Hasil analisis menunjukkan bahwa pada indikator 1 terdapat 69,74 \% mahasiswa memilih jawaban setuju dan pada indikator 2 terdapat 58,96 \% mahasiswa menjawab setuju. Hal ini berarti bahwa soal UTS yang diberikan sudah sesuai dengan materi yang diberikan. Soal UTS yang diberikan juga mampu menuntut mahasiswa untuk berpikir kritis. Soal UTS yang diberikan tidak hanya berfokuskan pada konten materi matematika saja namun juga membutuhkan pemahaman lebih dengan worldview yang benar. Selain itu jumlah soal UTS yang diberikan tidak terlalu banyak, sudah cukup mewakili untuk pertanyaan-pertanyaan terhadap materi yang ada.

Untuk mekanisme UTS dapat dikatakan termasuk kategori cukup baik karena mendapatkan persentase 58,96\%. Artinya penggunaan Moodle melalui laman univeristas tergolong cocok dan efektif digunakan untuk mengerjakan soal UTS Esensi Matematika. Sebagian besar mahasiswa menyetujui penggunaan Moodle untuk UTS, hal ini karena mahasiswa merasa puas dengan mengetahui langsung nilainya setelah selesai mengerjakan soal UTS Esensi Matematika. Hambatannya adalah mahasiswa mengaku panik ketika intenet di PC kurang lancar atau terdapat perangkat komputer yang kurang berfungsi secara maksimal.

Banyak manfaat yang diperoleh dari Moodle sebagai media untuk UTS, selain paperless mahasiswa juga dapat melihat langsung hasil/nilai dari Moodle itu sendiri. Menurut Marikar dan Jayarathne (2016) , penggunaan Moodle mendapat respon positif dari para penggunanya dan dapat meningkatkan prestasi belajar siswa didiknya. Moodle adalah salah satu fasilitas yang digunakan dalam penerapan Blended Learning. Mahasiswa dapat dengan mudah mengakses materi pembelajaran melalui PC mereka bahkan dengan smartphone.

Sebagai salah satu bentuk aplikasi dari pembelajaran online, penggunaan Moodle perlu diberikan untuk semester kedepannya dan dosen dapat memperbaharui materi yang ada. Seperti penelitian yang dilakukan oleh (Means et al., 2013) pembelajaran online efektif digunakan dalam pembelajaran, termasuk dalam memberikan kuis, tugas dan dilakukan UTS. Bahkan dosen juga dapat memberikan penilaian langsung melalui Moodle. Menurut I Kadek dan I dewa (2014), Moodle adalah perangkat lunak yang digunakan untuk menyampaikan materi pembelajaran secara online berbasis web, mengelola kegiatan pembelajaran serta hasil-hasilnya, memfasilitasi interaksi, komunikasi, kerjasama antar pengajar dan siswa. Sementara menurut (Thurlow et al., 2010), ada beberapa manfaat ujian online diantaranya: 1. Administrasi yang efisien 2. Meningkatkan kemampuan peserta ujian 3. Hasil ujian dapat langsung diketahui 4. Pengembangan item soal dapat dilakukan secara efisien 5. Tingkat keaslian/originalitas tes dapat ditingkatkan. 


\section{Histogram: Jurnal Pendidikan Matematika, 4 (1), 2020 - 62 \\ Tanti Listiani}

\section{KESIMPULAN DAN SARAN}

\section{A. Kesimpulan}

Dari hasil analisis dan pembahasan maka dapat disimpulkan bahwa task design yang dikembangkan perlu dituangkan dalam kontrak perkuliahan yang dilaksanakan untuk semester berikutnya. Task design perlu dimodifikasi agar tujuan pembelajaran dapat tercapai atau nilai UTS mahasiswa FIP dapat memenuhi standar yang diberikan. Pada modul pembelajaran perlu diperbaiki terutama penggunaan bahasa Inggris masih bisa digunakan, hanya memang perlu ditambahkan terjemahan terhadap istilah-istilah baru agar mahasiswa dapat memahami makna/isi dari modul. Untuk materi dan tugas perlu ditambahkan materi-materi yang mencakup materi integrasi. Sementara soal UTS perlu di modifikasi lagi yaitu disesuaikan kompetensi yang akan di capai dimana didalamnya juga mencakup soal-soal integrasi tanpa meninggalkan konten dari matematika. Penggunaan Moodle untuk pelaksanaan UTS juga dapat dipertimbangkan sebagai sarana pembelajaran yang lebih efektif dan efisien.

\section{B. Saran}

Ini merupakan penelitian pengembangan yang menggunakan 4 tahapan metodologi penelitian dari Didactical Engineering (DE). Pada penelitian ini baru menggunakan 2 tahap dimana tahap yang dilakukan adalah tahap analisis terhadap permasalahan serta rancangan untuk menyelesaikan permasalahan tersebut. Akan lebih baik jika dilakukan penelitian lanjutan yaitu melanjutkan tahap ke 3 yaitu Implementation, Observation and Data Collection dan ke 4 yaitu $A$ posteriori analysis. Hal yang perlu dilakukan untuk menyusun modul pembalajaran, tugas, soal-soal latihan, soal tes dan metode yang digunakan. Pengajar perlu melakukan pembelajaran yang mampu mengarahkan mahasiswa untuk memahami matematika bukan dengan sekadar hapalan saja lalu lupa, namun mahasiswa perlu untuk mendapatkan Enduring Understandin. Sehingga mahasiswa mampu memahami makna kehidupan yang sesuangguhnya dalam kelas, termasuk dalam belajar matematika. Menurut matematikawan Polandia (Stefan Banach, 18921945), mathematics is the most beautiful and most powerful creation of human spirit.

\section{UCAPAN TERIMAKASIH}

Ucapan terimakasih kepada mahasiswa FIP UPH yang telah menjadi subyek penelitian ini, terimakasih kepada FIP dan Program Studi Pendidikan Matematika serta LPPM UPH yang telah membantu serta memberikan saran bagi penulis sehingga penelitian yang memiliki No Penelitian: P-046-FIP/I/2019 ini boleh berjalan dengan baik. Segala Pujisyukur hanya bagi Tuhan. 


\section{Histogram: Jurnal Pendidikan Matematika, 4 (1), 2020 - 63 \\ Tanti Listiani}

\section{DAFTAR PUSTAKA}

Artigue, M., \& Mariotti, M. A. (2014). Networking theoretical frames: The ReMath enterprise. Educational Studies in Mathematics., 85, 329-355.

Brousseau, G. (2002). Theory of Didactical Situations in Mathematics (nineteenth ed.). New York, Boston, Dordrecht, London, Moscow: Kluwer Academic Publishers.

Clements, D. H., \& Sarama, J. (2004). Learning Trajectories in Mathematics Education. Mathematical Thinking and Learning, 6(2).

Evayanti, Maya. (2018). Desain Didaktis Konsep Garis dan Sudut Berdasarkan Realistic Mathematics Education (RME) pada Pembelajaran Matematika Sekolah Menengah Pertama (SMP). Bandung: Tesis S2 Universitas Pendidikan Indonesia.

Grevholm, B., Milman, R., \& Clarke, B. (2008). Function, Form and Focus: The Role Of Tasks In Elementary Mathematics Teacher Education. In B. Clarke, B. Grevholm, \& R. Millman (Eds), NY: Springer, Tasks in Primary Mathematics Teacher Education (pp. 1-5).

I Kadek dan I Dewa. (2014). E-Learning Berbasis Moodle. Yogyakarta. Graha Ilmu.

Indira, T., Somakim, S., \& Susanty, E. (2018). Kemampuan Berpikir Kritis Siswa SMP Melalui Pendekatan Pendidikan Matematika Realistik Indonesia. HISTOGRAM: Jurnal Pendidikan Matematika, 1(2).

Leung, A., \& Bolite-Frant, J. (2015). Designing mathematics tasks: The role of tools. In New ICMI Study Series.

Marikar, F., dan Jayarathne, N. (2016). Effectiveness of Moodle in Education System in Sri Lanka University. I, J Modern Education and Computer Science Modern Education and Computer Science, Vol 2 (2), 54-58.

Means, B., Toyama, Y., Murphy, R., \& Baki, M. (2013). The effectiveness of online and blended learning: A meta-analysis of the empirical literature. Teachers College Record, 115(030303),1-47.

Nickel, James. (2001). Mathematics is God silent?. Ross House Book: Vallecito California.

Nurhikmayati, I. (2017). Analisis Kesulitan Belajar Mahasiswa pada Matakuliah Matematika Dasar. Jurnal THEOREMS (The Original Research of Mathematics),2(1).

Pratiwi, V.U., Nurnaningsih, Setiyono, M.S. (2017). Penggunaan Modul Bahasa Inggris untuk Mengajar Mahasiswa PGSD. Prosiding Seminar Nasional Publikasi HasilHasil Penelitian dan Pengabdian Masyarakat, Universitas Muhamadiyah Semarang, 405-410.

Soeprianto, H. (2009). Penerapan Pembelajaran Nilai-Nilai yang Terintegrasi dalam Mata Pelajaran Matematika, Jurnal Educatio, 4(2), 29-37.

Simon, M. A. (1995). Reconstructing Mathematics Pedagogy from a Constructivist Perspective. Journal for Research in Mathematics Education, 26(2).

Simon, M. A., \& Tzur, R. (2004). Explicating the Role of Mathematical Tasks in Conceptual Learning: An Elaboration of the Hypothetical Learning Trajectory. Mathematical Thinking and Learning, 6(2).

Smith, B. (2016). Biblical Integration: Pitfalls and Promise. Bjupress, 1-7.

Thurlow, M., Lazarus, S. S., Albus, D., \& Hodgson, J. (2010). Computer-based Testing: Practices and Considerations. Practices and Consideration. Synthesis Report, 78: $1-4$ 
Histogram: Jurnal Pendidikan Matematika, 4 (1), 2020 - 64

Tanti Listiani

Watson, A., \& Sullivan, P. (2008). Teachers learning about tasks and lessons. In D. Tirosh, \& T. Wood (Eds.), Rotterdam, The Netherlands: Sense Publishers: The international handbook of mathematics teacher education, tools and processes in mathematics teacher education (pp. 109-134).

Widyastuti, Wijaya, A.P, Rumite, W., Marpaung, R.R. (2018). Minat Siswa Terhadap Matematika dan Hubungannya dengan Metode Pembelajaran dan Efikasi Diri. Jurnal Pendidikan Matematika, Vol. 13, No. 1, 83-100. 